\title{
Citizens' Dissatisfaction in Their Own Words
}

Procedural fairness addresses how authority is exercised, and how people experience it, which affects their views about the legitimacy of authorities. We know that when citizens assess their subjective experience in an encounter with the police, their judgment turns to a large degree on process-based criteria about the quality of decision-making and the quality of treatment they received. But we also know that factors beyond the immediate interaction influence citizens' subjective judgments about the immediate interaction.

Our police services survey gave respondents who were reportedly dissatisfied an opportunity to describe the reasons for their dissatisfaction in their own words. Our description of the sources of dissatisfaction with police treatment stem from the responses of 824 respondents ( 363 of whom called the police for assistance and 300 of whom were arrested). While there are differences in the overall number of individuals in each contact type, nearly all who were dissatisfied (ranging from 90 to 97 percent) went on to attempt to articulate the source of their dissatisfaction, regardless of contact type. Those who called the police for assistance and who reported that they were not satisfied with the way the police handled their problem were likewise given the opportunity to explain the source(s) of their dissatisfaction. Here again, nearly all of those who stated they were dissatisfied attempted to articulate why (677 of 700$)$.

The findings we derived from our analysis of respondents' views provide further evidence that assessments of police are influenced by factors beyond the immediate encounter. These include preconceptions about law enforcement as well as judgments about the interaction that are triggered at (and colored by) the earliest stages of the process, prior to interaction with the police (i.e., impressions of dispatch). 
We took an inductive approach to the textual analysis, as respondents' own words led us to the categories we formed. We identified ten main categories of sources of dissatisfaction, several of which include subcategories under the main theme. While we organize the discussion around the individual themes we identified, we also tie them to one or more elements of procedural justice typically discussed in the literature. Our review of studies that have examined procedural justice (most of which are quantitative) suggests that the same or similar items have not consistently been applied to the same subscales that make up elements of procedural justice. Our approach to coding and presenting the textual data enables us to place a theme we identified in one or more of the domains of procedural justice commonly identified in the literature.

In doing so we are able to better understand the factors that influence citizens' reported dissatisfaction. The closed-end items summarized in chapter 4 are corroborated by respondents' own words, indicating that the perceived character of the immediate interaction does shape citizens' satisfaction. In addition, respondents' stated reasons for dissatisfaction shed light and provide further support for the view that citizens' judgments are also shaped by forces outside of the immediate encounter, and often beyond the involved officers' control.

We turn now to a discussion of the categories that emerged when we contentanalyzed stated reasons for dissatisfaction without discriminating by the nature of the contact. Any one respondent could cite more than one reason for his/her dissatisfaction.

\section{STATED REASONS FOR DISSATISFACTION}

In order of descending frequency, the categories we identified included dissatisfaction stemming from: (1) the outcome of the contact; (2) perceived disrespect/loss of dignity; (3) perceived lack of concern; (4) inability to have one's voice heard; (5) perceived disparity in treatment and/or decision-making; (6) failure to provide information; (7) failure to respond to the scene; (8) failure to respect rights; (9) negative image of the police in general; and (10) external forces.

\section{Outcome}

When asked to provide a description of why they were not satisfied with how their problem was handled or how they were treated, many respondents focused on the outcome that followed the interaction. Within this category we identified two primary concerns: the officer was perceived to have not done enough (or even anything) to resolve the problem, or the ultimate resolution was not appropriate. The comments below exemplify those we characterized as typifying the "did nothing," "did not do enough," or "failed to resolve the problem" sentiment. Here, displeasure 
with the outcome seemed to rest on the perception that the police simply did not expend adequate energy or do enough toward problem resolution.

Nothing was done about the situation. Somebody had broke into my car they wrote a report and that was it.

They didn't do anything.

I had a break-in and I thought a report was going to be made but nothing has happened. They were polite but other than that it was a waste of time.

For one, I've been calling the police department with proof of what my neighbor was doing. Neighbor's son and herself have damaged my property and neighbor woman came up in my porch and spit in my friend's face. Police said couldn't do anything, they didn't have proof.

Because I am a homeowner and I have someone living in my apartment. The person had someone in the apartment that was destroying the property. They didn't do anything. They won't do anything.

I was assaulted by a former employee and they said there was nothing they could do.

I called several times about this problem, and still no tickets have been issued yet.

Because he tells me that they have to see it with their own eyes if my girlfriend had my baby in the car without the car seat. The officer overreacted when I showed them the car seat as proof that she took the baby without it and he got in my face and said, "I'll arrest you right now."

I called the police about my truck being stolen, they done nothing. I have made complaints.

They come to the scene and tell me there is nothing they can do about the drug dealers selling drugs in front of my business. I would appreciate if they would at least question the drug dealers. My property has been destroyed because the drug dealers know I'm calling the police, but the police don't do anything about it.

They left and left the problem there.

Because the problem wasn't handled they just swept it under the rug.

It was kids on my roof of my business and they were vandalizing my business. They said they could not do anything about it.

The work they did was superficial.

Because I feel further action should have happened with the situation, it makes you feel like why bother calling the police.

For others, the dissatisfaction turned not on police effort but on the outcome itself. Here, citizens felt that the officers' determination of how to handle the problem was incorrect. The quality of the decision was deemed unsatisfactory because its outcome was not the outcome the citizen felt he/she deserved.

They told me that they would arrest my neighbor and they didn't.

They should've charged someone with assault and no one was charged.

What happened was I gave the guy a ride and he stole my wallet out of the truck. It was on the dash. I was already driving away when I noticed it was gone and rushed back. I called the police when I noticed it was gone... I confronted him about the wallet and he gave it back. I was still on the phone with the police and they said because I got 
the wallet back they didn't need to do anything. I still wanted him prosecuted through and the police would [not] do anything.

The lady that was supposed to be arrested has not been arrested yet.

Among those who were not satisfied with the outcome, some went on to cite extenuating circumstances or justifications that should, in their opinion, have factored into the officer's decision.

I felt like I could have been given a warning since it was the first time I had been pulled over for that certain offense.

I wasn't trespassing and they wrote me a ticket for it and court was on a Saturday and I didn't know and then they issued a warrant for my arrest.

I went through a stop sign unknowingly. When the police stopped me he ask "just didn't feel like stopping at the stop sign today." I told the officer that I didn't see the sign and he just gave me a ticket.

Just don't understand why they had to put me in the cell when I had turned myself in for a warrant and I was honest enough to go in. I don't think that was necessary for them to do.

\section{Respect/Dignity}

We know that satisfaction is shaped by the extent to which officers interact with citizens in a manner that is perceived to be respectful and affords citizens the ability to maintain their dignity. And, indeed, this emerged in the open-ended responses. The respect category we formed captures the views of respondents who indicated that the basis for their dissatisfaction stemmed from their view that the officer(s) belittled them, were rude, and failed to show respect. In their own words:

He was being very rude and arrogant...

They treat you like an animal. I'm not used to being looked down on.

They talked to my mother and I and my sister like below human levels, like they didn't care about us. Bad mouthing my mother which was uncalled for ...

They were very impolite and they threatened me.

They were rude and conceited and aggressive.

They were taking a personal attitude instead of a professional attitude.

When he made me walk home instead of riding with my friend as I walked away he said "You're a fucking liar." I turned around and said "excuse me." He said "don't walk up at me." He said "you're going to jail." The other one was motioning me just to go on like he knew the other guy is a jerk, I turned around to walk away and he said it again and I just kept on walking.

They talked down on me like I am a piece of shit.

The way I was treated. Like I was a second class citizen.

One of them was extremely rude and I told them that... One of the officers said he didn't have time to argue and got in his car and left ... I was really surprised how rude he was.

... Very rude and very nasty... 
The way they treated me in broad daylight. He walked up to me and said, "I.D." They were very disrespectful. I know I did the wrong thing and threw a ticket on the ground. He started asking inappropriate questions, like how many tattoos I have and how many teeth are missing in my mouth and stuff that had nothing to do with what I was stopped for.

They always say something about my son, they laugh at him, they say, 'oh you got your son dressed like a little gangster', says the cops . . . I feel like they're treating my family like crap.

\section{Expressing Care and Concern}

Some citizens' dissatisfaction stemmed from the perception that police did not care about the problem and so minimized the seriousness of the respondents' views. When citizens perceive that their own needs and concerns are viewed as a "waste of time" by either the officer or the department, this is a source of displeasure. Many times, citizens appear to draw this inference from specific actions or inactions (e.g., not getting out of the police car when speaking to the citizen). Similarly, department policy around response priority sends a signal about the worthiness of the problem; regardless of whether or not the citizen is able to disentangle department policy on response priority from an individual officer's decision to take his/her time to the scene, the citizen is left unhappy. Responses in this category closely overlap with other themes we identify, particularly "respect," "outcome," and "voice." However, we captured this category separately because it serves to explain directly why certain decisions or actions leave citizens questioning the motives of officers.

Showed no compassion. It was a very emotional situation, no human side of their selves showed, no compassion.

They were very unsympathetic with me. I felt they didn't care at all about [my] being attacked in my own home.

They disregarded my state of mind and there were thirteen cop cars all men no women and I'm telling the officers I'm on parole and on house arrest and that I needed to go home and asked for a ride. When I was walking home the officer drove by me and honked the horn trying to be funny.

Because they didn't think it was important enough for them to come. They don't like to be bothered...

Because obviously they didn't care about my call and they would probably be at Dunkin' Donuts.

They acted like I was bothering them bringing it to their attention.

The regard and the seriousness of my situation was disregarded as non-important.

Didn't care about the incident at all ... We asked for assistance getting a tow truck and he told us it was on us to get one, and he was more worried about getting to where he was at and not concerned about the situation at all.

Because they should have gotten out of the car and spoken to her instead of just watching me fight with her. 
Because the officers didn't get out of the car or anything. They sit and do nothing but play with computers and then do nothing.

Response time can depend on a variety of factors including staffing, call volume, and call type, and it includes both dispatch delays and patrol units' travel time. Citizens' satisfaction with response time is also influenced by their expectations, which may not be realistic. While the department should do what it can to manage citizens' expectations regarding response time, it is surely the case that there will be those whose expectations cannot be met.

The response time, in trying to get an intoxicated person off the road, they never stopped by to even talk to me.

Because they don't care about other people. I mean we got into an accident and they never showed up. It took hours before they showed up. That's not right. He could have gotten hit again.

It took too long for them to arrive, and they were not helpful. It seemed like they did not want to be here and wanted to leave as soon as they could.

They never showed up for like three hours, and actually in that time span I saw some officers hanging out in a parking lot chitchatting.

My car was broken into and the cops didn't show up until 3-4 hours later. Told me I was a low priority.

\section{Voice}

Citizens assess the quality of the service provided by police, at least in part, by the opportunity they are given to tell their side of the story, be heard, and to explain themselves. Several examples of respondents' comments along these lines provide richer detail on why this is important to citizens and what they experience when they believe they have been denied the opportunity to express themselves.

Did not care about us or the situation... Didn't ask any questions.

Because when they came up to my door after 911 call they wouldn't let me tell my story. The officers told him that he should call CPS, said that they didn't want to hear his side of the story...

They don't like, listen to what you're trying to explain to them about what's going on. And they automatically jump to conclusions about how to best handle the situation.

They weren't listening, not paying attention...

For some citizens, the issue was not simply that the officer failed to listen or get their input, but more so that they were perceived to have given more opportunity for other involved parties to be heard. The officers' neutrality was in question. Displeasure stems from the belief that the officer gave more weight or input to the other party (in effect "taking the other person's side").

They wouldn't let me explain my side of the story. I never once said anything wrong to them and they ignored me when I asked them questions... 
The police don't take the time out to listen to both side of the story.

I can't figure out why he would take a pedophile's word over mine, the officer, he blew me off.

After I got hit by the car I bought by my ex-girlfriend they were totally on her side because she called before I called. They did not take a statement from me at all. I haven't signed anything yet. They did take a statement from my ex-girlfriend after the accident... They were taking the other person's words over mine which was not right.

The female cop was sort of real cocky. She wasn't listening to my side and I had every right to talk to the people, and she took their side and she wouldn't listen to me.

Listened to the other guy more and took down his statement as gold and mine wasn't.

\section{Disparity}

Satisfaction can turn on the extent to which a person believes they are treated fairly and shown neutrality. When the decision an officer makes or the way s/he treats a citizen is believed to be biased, citizens are dissatisfied. Citizens feel they have been treated unfairly when they believe that they are singled out for "special" treatment (e.g., stopped or ticketed) by virtue of personal attributes or perceived stereotypes inferred from such things as the type of neighborhood in which the citizen lives or the sort of car he or she drives. The following comments provide further detail:

... Very racist. I don't remember exactly what it was but the officer was being very racial.

Because they seemed racist.

Because they don't treat you like people. I feel because I'm black they treated me differently.

They told me to get out of the ambulance and then he said something I couldn't understand and to me they were trying to be racist or something like that...

I feel like I was treated unfairly because I'm a black female.

It was more common for respondents to question the fairness or legitimacy of police actions or the officer's honesty than it was for them directly to suggest racism. Respondents clearly believe they were singled out improperly (a violation of their rights) and received police attention they did not deserve.

Because they treated me differently from the way they were treating other people.

They know I'm on parole, they treat us like scavengers. So they pick on me...

I felt like I was being targeted. They didn't have a legitimate reason to stop me...

The cops know me from previous times so they target me.

Because I was in a not so nice area on the west side. I was treated like a criminal and I was being called names and treated not so nice.

\section{Failure to Provide Information}

Dissatisfaction also turned on the perception that officers failed to provide information and explain themselves. We know that people want to understand what 
they are experiencing, and in order to make sense of experiences they tap into available information, filling in missing information (accurately or inaccurately). Responses in this category encompass three related basic issues: (1) a failure to explain decisions and actions; (2) a failure to follow up to provide information after the immediate incident; and (3) the provision of incorrect information.

In some cases, the issue seems to be straightforward displeasure around not knowing what is happening or why decisions are being made as they are. In other cases, there is a deeper underlying issue. A failure to provide information opens the door for citizens to question the trustworthiness of officer motives. Specifically, when officers fail to explain themselves (at all or enough) to citizens' satisfaction, respondents question the basis for the police action or question the veracity of the explanation given for the action.

I feel like if you give someone a ticket you should be able to explain why.

My view is when you have rookies they always try and take control. When I asked what my charges were they wouldn't tell me what they were. They need to fight real crime, not little petty crime.

The police gave me a ticket and could not explain why he gave me the ticket...

They would not tell me what I was being arrested for they just manhandled me. And didn't explain until after I was in handcuffs. The one officer was somewhat under control. The other was a young punk and was above the law that was full of himself. I would have cooperated if they would have just tell me what was going on.

Very unprofessional, didn't explain anything, I was completely unaware why I was stopped.

They did not inform me of anything.

They did not explain themselves.

I didn't get an idea if anything was going to be done or not.

Perceived failure to follow up with citizens and provide information after an incident (setting aside the issue of whether follow-up is warranted) is a source of dissatisfaction with the quality of police services. Some citizens simply described the problem as "no follow-up," while others went on to explain how the failure to follow up made them feel. Here, displeasure is rooted in uncertainty about the outcome of an incident. It may be that satisfactory problem resolution need not involve an arrest or lengthy investigation. For some, it may be that managing their expectations (e.g., regarding the likelihood of a follow-up call or a full investigation) could have a positive impact.

I don't know what the outcome was.

I reported a situation that was rather dangerous and no one did any follow-up. It was a child that might have been endangered.

I was very unsatisfied because the police officer that took my info didn't follow up with anything...

They never called me back. They said a lot of stuff... 
I called the police about fireworks being set off in the neighborhood. No way of knowing if things were dealt with...

A gun was pulled out on my son. They told me that they would contact me back to let me know what they find out about the incident, and they still have not contacted me back.

He took a report and said that the detective would get back to me, and I still haven't heard nothing.

\section{Failure to Respond to the Scene}

Dissatisfaction also stemmed from the belief (correct or incorrect) that no officer ever responded to the citizen's call for assistance.

Because the dispatcher told us to stay in an area where I was in harm's way and then the police didn't show up. I was willing to put myself in danger to help someone, but the police were not.

Because the police never showed.

No one responded at all.

\section{Personal Rights Violated}

The belief that one's rights were violated was a source of dissatisfaction. Responses in this category centered on either the use of force, failure to read an individual his/her rights, or perceived improper searches of a person or vehicle. Citizens in this category do not draw favorable inferences about officer motives. The following examples illustrate the use of force issues we characterize under perceived violation of rights. The perceived use of force fell along a continuum from unnecessarily tight handcuffs to displays of physical force including pushing and hitting.

When I was in the back of the car, my handcuffs were on extremely tight and I was losing feeling in my fingers, and I told the officer and when we were at the station he went and started talking to someone else when I felt that he could have loosened them up...

When the police pulled up on the scene I was injured and one arm and hand was injured, and I was put in cuffs anyway. When I requested to be handcuffed in the front they would not listen. I didn't know how bad the injury was. I bled all over the police car... The guy in the ambulance saw how bad the injury was and he put the cuffs in the front.

They slammed me up against the wall, bent me over the railing and then pulled my arms behind my back and handcuffed me. I am only 5'6" and weigh $115 \mathrm{lbs}$. They were both over 6 feet... They just manhandled me...

They stun-gunned me. I fell to the ground. I was not resisting anymore and they almost pulled my arm out of the socket. Two officers jumped on me, and I had cuts and bruises all over me. I weigh 165 and two 240 pound [officers] jump on me. I was not resisting at this point. Pushing my face into the concrete. 
For others, a baseless police action was at the root of the perceived rights violation. In this category we capture comments from which we inferred the citizen was getting at the issue of reasonable suspicion:

He acted like I was a felon and there was no reason to pull me over. I was behind two 45 degree angles, claiming I ran a light but he was 500 yards behind me. You don't have to lie, and pull me out of my car.

Because they took me out of the car and I wasn't the driver. Also because there was no reason to pull us over.

I was stopped for supposedly the tint on the window, but when I was on X-street it was dark...

I wasn't speeding, and they said I was. He was filling his quota.

I felt it was an inappropriate stop and the evidence of it being an inappropriate stop there was no ticket or warning.

They just arrested me just to make an example for my friends. I deal with this cop all the time.

I feel that they lied. He was not speeding when he was stopped at the traffic stop. His foot was not on the accelerator at all ...

I didn't like it when I was pulled over for an improper cause saying my lights didn't work.

Some believed their rights were violated when the officer allegedly failed to read them their rights:

They had no reason to arrest me. They did not read my rights to me until in front of the judge.

They never read me my Miranda rights...

Also included in rights violation category were comments highlighting the citizen's belief that s/he had been subjected to an improper search, perhaps because s/he did not give consent or, even with consent, the search seemed unnecessary given the nature of the incident that gave rise to the police contact:

They didn't ask to search my person and they had no right to search my person...

They pulled me over for a loud muffler which I didn't have, and they searched my vehicle and that was kind of unfair to me.

There has been a few occasions that I have been stopped because my music is too loud and they have to search the vehicle, I don't think that is right.

They wanted to search the vehicle. I said no and they said either they can give me tickets or they can search my vehicle.

Last, the personal rights category captures references to dissatisfaction driven by a belief that one's privacy was violated. For example, respondents who called the police to report a neighbor for loud music or to report drugs being sold in the area and who perceived that the police violated their right to confidentiality. 
When we call them to tell about drugs they go back and tell the people we called them on. I worry we could get killed. They tell the drug people and they know where I live.

\section{Negative Image of the Police Generally}

What emerged when some people described their dissatisfaction with how their contacts were handled were negative feelings about law enforcement in general. The responses in this category lend support to research findings that citizens enter an encounter with preconceived views of law enforcement. We can suppose that these are people whose subjective experiences with the police are determined by their prior attitudes toward the police, and whose attitudes are probably not susceptible to change as a result of even superior police performance in an encounter.

Two primary issues emerged within the category of generally negative views of the police. The first centered on police officers and their perceived shortcomings as a group, and the second focus was at the specific department-level and its practices more generally:

I don't really know. I just don't like cops period.

The police have an attitude that they are always right no matter what the situation is. Frankly, I would not call them unless someone was being stabbed or flashing a gun.

Because they are just fucking assholes. They like to push you around and tighten handcuffs too tight. They are just known to be crooked SOBs. They are just as guilty as we are.

Because the police are a bunch of idiots.

Well for one, the majority of the officers cheat you. They have a problem. They judge you.

Police have the right for discretion, but regardless of the situation they need to maintain composure, respect, and self-dignity. If police go around acting like high school bullies then they are ignorant. Police need to be proactive not reactive. If they act like the criminals they apprehend then what makes them so different?

A lot of them like to take their badge and abuse their authority.

I just don't like the way they talk down to you, they disrespect you and are forceful. I don't have a high regard for the police department.

I believe that when [investigating] a break-in or vandalism that they should keep track and then inform you of the crimes in your neighborhood ... they should take a proactive view.

\section{External Forces}

For some respondents dissatisfaction was shaped by other actors in the process. Among those who expressed dissatisfaction with the police, a number specified that their initial contact with dispatch was the cause of their dissatisfaction. Some respondents even went so far as to distinguish that they did not have an issue with 
the responding officer or actions taken after they placed the call to dispatch. Others appeared to be dissatisfied with how they were treated at the jail subsequent to an arrest:

The dispatcher was also very rude to my wife.

The dispatcher... he disrespected me by the tone of his voice.

Dispatchers were very indifferent about it, "Well we will try to get over there."

While I was in jail they treated me terribly and it was cold...

When I was in the holding tank they put nine girls in one small tank, it's dirty, we complained about something biting us...

They would not let me call my family. There were people in the jail that were there for something more serious than what I did and they were treated better than I was.

\section{SUMMARY}

The findings discussed above reveal the salient influences on dissatisfaction, shed light on why they are sources of dissatisfaction (the logic citizens apply when they judge an interaction), and how seemingly discrete factors "feed or fuel" one another. With respect to factors associated with the immediate encounter, respondents' own descriptions of what shaped their dissatisfaction fit within categories previously identified in the literature. Further, respondents' own words substantiate findings from quantitative measures that while outcomes matter, satisfaction is also driven by elements of procedural justice, including voice and the quality of interpersonal treatment, and also the perceived quality of decision-making. We further find that citizens' assessments of how they were treated or how their problem was handled are shaped by influences that are beyond the responding officer's control.

One of the "values added" through letting respondents frame their experience in their own words is that the data provide a level of detail and context not generally available through quantitative data. This level of detail shows the concrete factors citizens attend to when assessing the quality of their interaction with the police and, moreover, shed light on why they matter to citizens. This level of detail can give purchase to police managers and trainers striving to provide specific guidance to law enforcement on how to move toward a more procedurally just model of policing. They also "simplify" and reduce ambiguity around common procedural justice concepts and phrases.

Secondly, the open-ended responses corroborate what quantitative data has found, primarily through surveys of citizens. In addition, they reveal that citizens do not separate the behavior of the officer with whom they interacted from others in the process or from law enforcement more generally. While this is not surprising, it is important to draw out. Feedback from citizens is considered an important piece of assessing police performance at both the department level and the 
individual officer level. However, survey data offer citizens' perceptions that are only partially shaped by officers' performance. Also, departments seeking to promote more procedurally just policing could, perhaps, achieve more demonstrable success were these values to be inculcated among their own personnel, as well as among actors from other involved agencies including, but not limited to, dispatch and jail staff. Even with that, moving the dial on improvements in citizens' perceptions of the procedural justice with which police perform is a difficult task. 